\title{
Article/Artigo
}

\section{Paracoccidioidomycosis in the State of Maranhão, Brazil: geographical and clinical aspects}

\author{
Paracoccidioidomicose no Estado do Maranhão, Brasil: aspectos geográficos e clínicos
}

\author{
Wilma Batista de Matos ${ }^{1,2}$, Gisele Maria Campelo dos Santos ${ }^{3}$, Vitor Emmanuel Bouças da Silva ${ }^{4}$, \\ Eloísa da Graça do Rosário Gonçalves ${ }^{1,2}$ and Antonio Rafael da Silva ${ }^{1,2}$
}

\begin{abstract}
Introduction: The study aimed to show the situation of paracoccidioidomycosis in the State of Maranhão, Brazil. Methods: This study is a descriptive case series developed in two stages. First, a survey of cases originating from the State of Maranhão at the Instituto de Doenças Tropicais Natan Portela, Piauí (IDTNP) from 1997 to 2007, and second, the clinical description of 29 cases diagnosed in the Centro de Referências em Doenças Infecciosas e Parasitárias, Maranhão (CREDIP) from 2004 to 2010. Results: Two hundred and sixteen cases have been cataloged at the IDTNP. West, east, and central regions of the State of Maranhão recorded 90.3\% of cases proving to be important areas for study. The western region, with a prevalence of 10.8/100,000 inhabitants, has a significantly higher proportion of cases than the northern, southern, and eastern regions $(\mathrm{p}<0.05)$. The occurrence was higher in men with $89.3 \%$ of cases, and the male-to-female ratio was $8.4: 1$. The majority of patients were older than 20 years, lived in rural areas, and had farming or soil management as main occupation (73.8\%). At CREDIP, 29 cases were diagnosed, of which 26 (89.6\%) had multifocal manifestations. Mucous tissues were involved more (75.8\%) frequently, followed bylymph nodes, skin, and lungs with $65.5 \%, 39 \%$ and $37.9 \%$, respectively. The diagnosis was made by combining direct examination, culture, and histopathology. Conclusions: The study shows the geographical distribution and the epidemiological and clinical aspects of paracoccidioidomycosis, revealing the significance of the disease to the State of Maranhão.
\end{abstract}

Keywords: Paracoccidioidomycosis. State of Maranhão. Epidemiology.

\section{RESUMO}

Introdução: O estudo teve o objetivo de mostrar a situação da paracoccidioidomicose no Estado do Maranhão, Brasil. Métodos: Trata-se de um estudo descritivo do tipo série de casos, desenvolvido em duas etapas: na primeira, levantamento de casos originários do Maranhão, atendidos no Instituto de Doenças Tropicais Natan Portela, Piauí (IDTNP), de 1997 a 2007; na segunda, descrição clínica de 29 casos diagnosticados no Centro de Referência em Doenças Infecciosas e Parasitárias, Maranhão (CREDIP), no período de 2004 a 2010. Resultados: Foram catalogados 216 casos no IDTNP. As regiões Oeste, Leste e Centro do Maranhão registraram $90,3 \%$ destes casos, demonstrando serem áreas importantes para estudo. A região oeste, com prevalência de 10,8/100.000 habitantes, apresenta proporção de casos significativamente maior que as regiões Norte, Sul e Leste $(\mathrm{p}<0,05)$. A ocorrência foi maior em indivíduos do sexo masculino (89,3\% dos casos), sendo a proporção entre homens e mulheres de 8,4:1. A maioria dos acometidos possuía mais de 20 anos, residia na zona rural e tinha como principal ocupação a lavoura ou o manejo do solo (73,8\%). Foram diagnosticados 29 casos no CREDIP, dos quais $26(89,6)$ tinham manifestações multifocais. $\mathrm{O}$ acometimento mais comum foi de mucosas $(75,8 \%)$, seguindo-se gânglios, pele e pulmões com $62 \%, 39 \%$ e 34,7\%, respectivamente. A confirmação do diagnóstico foi feita pela combinação de exame micológico direto, cultura e histopatológico. Conclusões: $\mathrm{O}$ estudo mostra a distribuição geográfica, os aspectos epidemiológicos e clínicos da paracoccidioidomicose, revelando a importância da doença no Estado do Maranhão.

Palavras-chaves: Paracoccidioidomicose. Estado do Maranhão. Epidemiologia.

1. Centro de Referência em Doenças Infecciosas e Parasitárias, Núcleo de Patologia Tropical e Medicina Social do Maranhão, Departamento de Patologia, Universidade Federal do Maranhão, São Luis, MA. 2. Programa de Pós-Graduação em Saúde e Ambiente, Universidade Federal do Maranhão, São Luis, MA. 3. Curso de Graduação em Medicina, Universidade Federal do Maranhão, São Luis, MA. 4. Coordenação de Engenharia, Unidade de Ensino Superior Dom Bosco, São Luis, MA.

Address to: Dr. Antonio Rafael da Silva. Centro de Referência em DIP/Dept ${ }^{\circ}$ de Patologia/UFMA. Praça Madre Deus 02, Bairro Madre Deus 65025-560 São Luis, MA, Brasil.

Phone: $55983221-0270$

e-mail: credip@ufma.br

Received in 30/07/2011

Accepted in 27/10/2011

\section{INTRODUCTION}

Over the last decade, frequency, demographic characteristics of the affected population, and geographic distribution of paracoccidioidomycosis have been recorded. It is observed that over time and by region, the incidence of the disease has changed without having the circumstances of these changes defined ${ }^{1}$. Due to this situation and with the disease not usually reported to the government, there is no accurate data on morbidity in Brazil. Thus, knowledge on endemic regions and clinical and epidemiological information are from the case reports of the disease and its causal agent, Paracoccidioides brasiliensis ${ }^{2-8}$.

Brazil has shown approximately $80 \%$ of cases in the Americas. Southeast, midwest, and south regions have more information, believing that the incidence of paracoccidioidomycosis (PCM) in these endemic areas vary from 3 to 4 cases per million up to 1 to 3 cases per 100,000 inhabitants per year9. Although considered rare in the Amazon, in the last two or three decades, the number of cases has been increasing, especially in areas recently occupied, with large areas of deforestation for agricultural activities, livestock, and eucalyptus planting ${ }^{10}$.

In the State of Maranhão, Brazil, over $60 \%$ of the population lived in the countryside and worked in the agriculture during the 1960s and 1970s. Since the 1970s, the western part of the state is the representative region for the expansion process of new agricultural frontiers and also the largest receiver of migratory flows from other states ${ }^{11,12}$.

Study of 286 patients with paracoccidioidomycosis seen at the Instituto de Doenças Tropicais Natan Portela (IDTNP), Piaui, in 1995, showed that $51.4 \%$ had origin in the State of Maranhão ${ }^{4}$. The same author describes cases from other states and confirms that the IDTNP is the health service that concentrates the highest casuistry of paracoccidioidomycosis in the north and northeast of Brazil. These data confirm findings of other authors who described autochthonous cases from Maranhão ${ }^{13,14}$. These reports have stimulated the team of the Centro de 
Referência em Doenças Infecciosas e Parasitárias, Universidade Federal do Maranhão (CREDIP-UFMA) to perform studies about the reality of the disease in Maranhão.

This study aimed to show the geographic distribution of paracoccidioidomycosis in the State of Maranhão diagnosed at IDTNP from 1997 to 2007 and make a clinical description of cases diagnosed and treated at CREDIP-UFMA from 2004 to 2010.

\section{METHODS}

\section{Description of the study area}

The State of Maranhão is located in the southern hemisphere, occupying the western portion of the northeast of Brazil and having as boundaries the Atlantic Ocean to the north, Piauí to the east, Tocantins to the south and southwestern, and Pará to the northwest. It is one of the nine states of Legal Amazon and has an area of $331,933 \mathrm{~km}^{2}$, a population of $6,184,538$ inhabitants, and a density of 18.6 inhabitants ${ }^{15}$ per $\mathrm{km}^{2}$.

The state is composed of 217 municipalities, which are distributed in five geographic regions: North, in the shoreline; west, along the lines of the large rivers (Gurupi, Tocantins, Itinga, and Araguaia); south, including the Mangabeiras Plateau; center, encompassing Mearim River; and east, in the course of Parnaíba River. The climate is tropical, and there are 12 hydrographic basins, flooded fields, swamps, savannas, palms, and rainforests ${ }^{11,16}$.

Its economy is centered on regional agriculture, and the main crops are rice, bean, cassava, corn, and sugar cane. The cultivation of eucalyptus and soybean is done mechanically in large areas that are already devastated. The main products of the vegetal extraction are firewood and logs for charcoal production, a common practice in the state, especially in the west region ${ }^{11,16}$.

\section{Characteristics of the study}

Descriptive study of case series type was conducted in two stages: first, the researchers proceeded to survey the cases from the state of Maranhão recorded at Instituto de Doenças Tropicais Natan Portela (IDTNP), Piauí, from 1997 to 2007, and second, a clinical description of the 29 cases diagnosed and treated at the Centro de Referência em Doenças Infecciosas e Parasitárias (CREDIP-UFMA) from 2004 to 2010 was made.

\section{Statistical analysis}

Demographic variables, including age and sex, were analyzed. Proportion test to compare the occurrence of cases among regions, exact test to evaluate the association between age and sex, and correspondence analysis to assess the similarity of the disease between men and women and to compare with their age were applied, considering $95 \%$ confidence interval.

\section{Ethical considerations}

The study was submitted to the Ethics Committee in Research of the University Hospital of UFMA (protocol number 174/08).

\section{RESULTS}

The first step of the study was to catalog 216 patients with paracoccidioidomycosis from the State of Maranhão. It was observed that there was a higher number of cases among men, with an average of 18 cases per year, while among women, the average was 2 cases per year (Figure 1). The data indicated that there was no tendency to increase or decrease over the period (1997-2007), but there were fluctuations around the central values, which was observed by adjusting the series through the technique of moving averages.

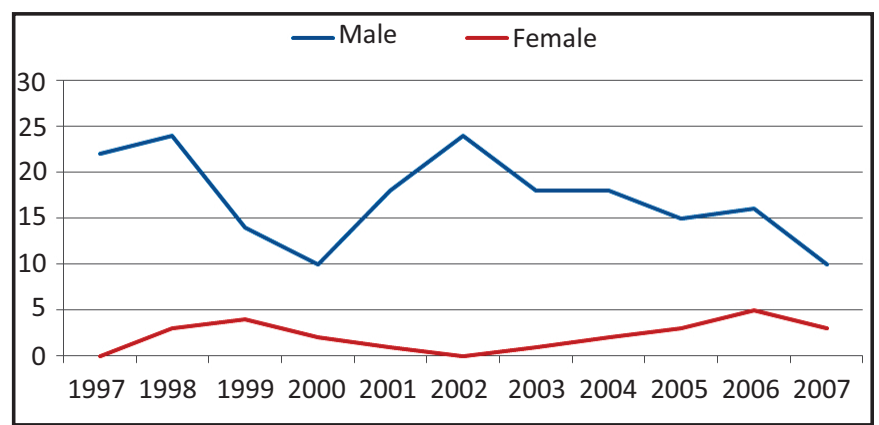

FIGURE 1 - Historical series of cases of paracoccidioidomycosis by gender and year, originating from the State of Maranhão, Brazil, and diagnosed at Instituto de Doenças Tropicais Natan Portela, Piauí, 1997 to 2007.

\section{Geographical distribution}

The distribution of the cases by geographic region of the State of Maranhão shows that the highest prevalence rates are found in the central and in the west regions, with prevalence rates of 8.60 and 10.81 cases per 100,000 inhabitants, respectively, while the lowest prevalence is in the north with $0.76 / 100,000$. The west region has a higher prevalence rate than north, south, and east regions, $\mathrm{p}<0.05$ (Table 1).

TABLE 1 - Prevalence of paracoccidioidomycosis originating from the State of Maranhão, Brazil, and diagnosed at IDTNP-Piauí, according to geographic region and gender, 1997-2007.

\begin{tabular}{lcccccc}
\hline Regions & Inhabitants & Municipalities & Male & Female & Total & $\begin{array}{c}\text { Prevalence/ } \\
\mathbf{1 0 0 , 0 0 0}\end{array}$ \\
\hline North & $1,050,808$ & 4 & 8 & - & 8 & 0.76 \\
South & 179,511 & 8 & 8 & 1 & 9 & 5.01 \\
East & 746,885 & 17 & 38 & 1 & 39 & 5.22 \\
Center & 616,374 & 24 & 46 & 7 & 53 & 8.60 \\
West & 989,503 & 27 & 93 & 14 & 107 & 10.81 \\
\hline Total & $3,583,081$ & 80 & 193 & 23 & 216 & \\
\hline
\end{tabular}

IDNTP: Instituto de Doenças Tropicais Natan Portela; $\mathrm{p}=0.05$.

The west, east, and center regions concentrated $90.3 \%$ of the cases (Figure 2). The municipalities in these regions with the highest number of cases were Açailândia with 22 cases, Buriticupu with 16, Imperatriz with 13, and Santa Luzia do Tide with 9, resulting in 56.7\% of the cases of the west region; Timon with 12 and Caxias with 9 accounted for $53.8 \%$ of the east region; Barra do Corda and Grajaú with 5 cases each and Arame, Bacabal, Pedreiras, Pio XII, and São Domingos with four cases each accounted for $62.1 \%$ of the cases in the central region.

\section{Demographic aspects}

There were 193 males and 23 females, resulting in a male-tofemale ratio of 8.4:1 (Table 2). The age ranged from 3 to 71 years and $81.5 \%$ of the patients were older than 20 years. Regrouping the individuals into male and female, older and younger than 20 years, the male-to-female ratio among the individuals over 20 years was 10.7:1 (2.7 times greater than the involvement of children under 20 years, whose male-to-female ratio was 4:1). 


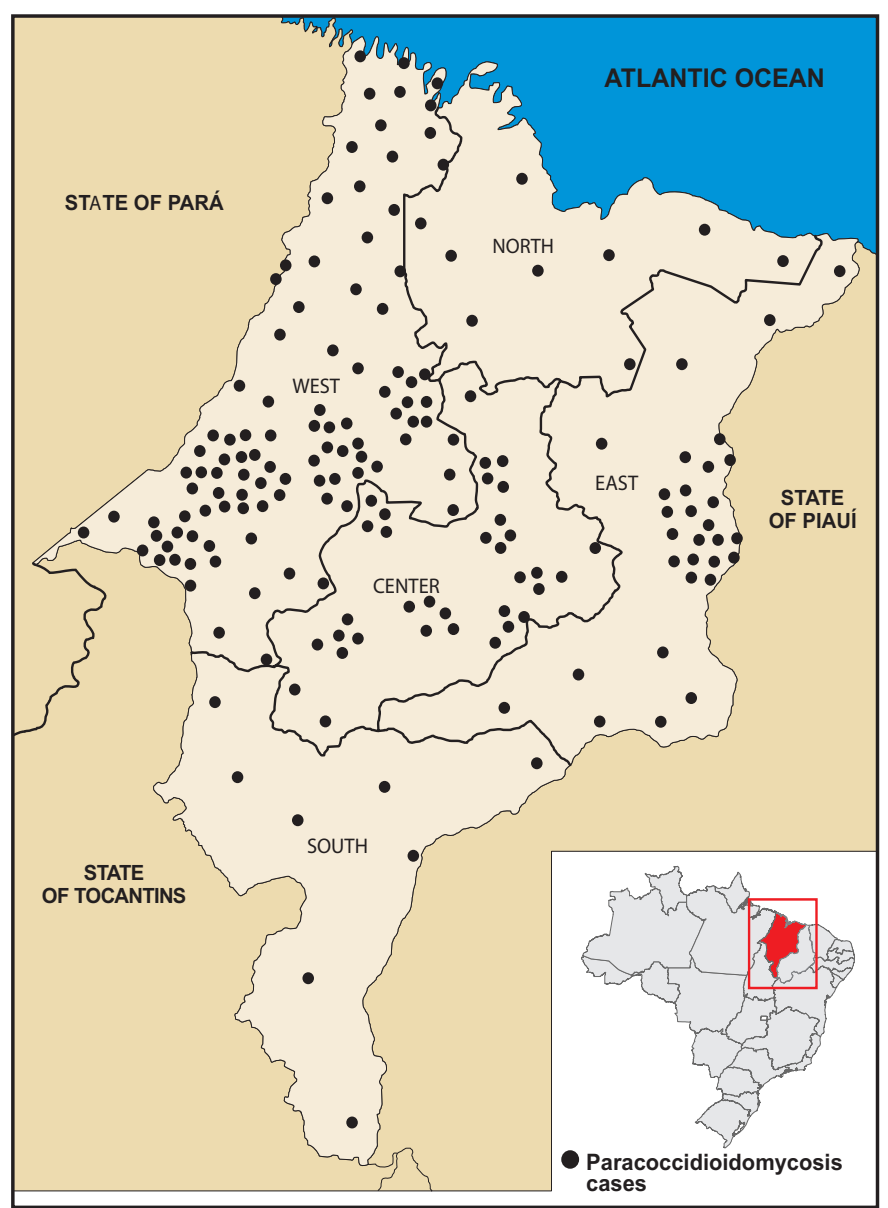

FIGURE 2 - Geographic distribution of paracoccidioidomycosis cases originating from the State of Maranhão and diagnosed at Instituto de Doenças Tropicais Natan Portela, Piauí, 1997 to 2007.

TABLE 2 - Distribution of patients with paracoccidioidomycosis proceeding from the State of Maranhão, Brazil, attended in IDTNP-Piauí, according to age and gender, 1997-2007.

\begin{tabular}{lccccc}
\hline \multirow{2}{*}{ Age (years) } & \multicolumn{4}{c}{ Gender } \\
\cline { 2 - 6 } & male & female & total & $\%$ \\
\hline $0-19$ & 32 & 8 & 40 & 18.5 \\
$20-29$ & 34 & 6 & 40 & 18.5 \\
$30-39$ & 35 & 4 & 39 & 18.0 \\
$40-49$ & 42 & - & 42 & 19.4 \\
$50-59$ & 34 & 2 & 36 & 16.7 \\
$\geq 60$ & 16 & 3 & 19 & 8.8 \\
\hline Total & 193 & 23 & 216 & 100.0 \\
\hline IDNTP: Instituto de Doenças Tropicais Natan Portela; $\mathrm{p}=0.02$ & &
\end{tabular}

Analysis of the data in Table 2 rejects the independence hypothesis by showing that there is an association between sex and age group for those affected of paracoccidioidomycosis $(\mathrm{p}=0.02)$. The evaluation of similarity shows that among younger women and among adult men, there is a greater tendency for the disease to manifest.

\section{Occupational activity}

Records of occupation were available for 153 patients, of which $113(73.8 \%)$ had activities related to soil use ( 92 were farmers). The others were students, businessmen, housewives, and retirees.

\section{Clinical study}

The second step of the study described the findings on the 29 patients who were diagnosed at CREDIP/UFMA. West and central regions were the original place of $26(89.7 \%)$ patients. Regarding gender, $26(89.6 \%)$ were male, while only $3(10.3)$ were female. Twenty three patients $(79.3 \%$ ) were 20 to 59 years old. The youngest patient was 14 , and the oldest was 78 . Five patients were using tobacco and alcoholic beverages regularly; 12 were using alcoholic beverages only; and one, apart from drink and cigarettes, was a drug addict.

Twenty-two (75.8\%) patients reported being sick from 7 months to 2 years, and 7 patients had the disease in less than 6 months. The general clinical status was regular in $10(34.5 \%)$ patients and critical in 19 (65.5\%). Some patients showed signs of severity, such as continuous fever and immense weight loss.

Clinically, the patients were skinny (65.5\%), along with other symptoms like fever (31\%), chills (20.7\%), headache (20.7\%), followed by skin lesions like impetigo and ulcer on the face and extremities (37.9\%), oral mucosa involvement (75.8\%), rectal ulcerations (6.9\%), diarrhea $(20.7 \%)$, damage to the oropharynx accompanied by severe salivation, pain on swallowing, and difficulty in feeding (37.9\%), pallor (44.8\%), increase in lymph nodes (75.8\%), respiratory manifestations (48.2\%), with productive cough, bloody sputum, or dyspnea. Four (13.8\%) patients had involvement of larynx. In one patient, the disease began with severe abdominal pain. The liver was palpable in five (17.2\%).

It was found that $26(89.6 \%)$ patients had multifocal involvement ( 17 with involvement in two organs and 9 patients in three organs), and 3 patients had involvement of a single organ.

In those patients who had two organs involved, the associations were mucosa and lymph nodes (43.7\%), lymph nodes and lung (18.7\%), skin and mucosa, skin and lymph nodes, and mucosa and lung (12, 5\% each). In patients with involvement of three organs, the associations were skin, mucosa, and lymph nodes; skin, mucosa, and lung; mucosa, lymph nodes, and lung (33.3\% each). In those who had involvement of one organ, the affected part was the skin, mucosa, or ganglion (Table 3).

TABLE 3 - Distribution of patients with paracoccidioidomycosis diagnosed at CREDIP-Maranhão, according to affected organs, 2004-2010.

\begin{tabular}{lccccccc}
\hline & & & \multicolumn{5}{c}{ Affected organs } \\
\cline { 5 - 8 } Age (years) & Male & Female & skin & mucous & ganglia & lungs* & larynx \\
\hline $0-9$ & - & - & & & - & - & - \\
$10-19$ & - & 1 & - & 1 & - & - & - \\
$20-29$ & 3 & - & 1 & 2 & 2 & 1 & - \\
$30-39$ & 9 & 1 & 4 & 7 & 7 & 4 & 3 \\
$40-49$ & 4 & - & 4 & 2 & 2 & 1 & 1 \\
$50-59$ & 5 & 1 & 1 & 6 & 5 & 2 & - \\
$\geq 60$ & 5 & - & 1 & 4 & 3 & 3 & - \\
\hline Total & $\mathbf{2 6}$ & $\mathbf{3}$ & $\mathbf{1 1}$ & $\mathbf{2 2}$ & $\mathbf{1 9}$ & $\mathbf{1 1}$ & $\mathbf{4}$ \\
\hline
\end{tabular}

CREDIP: Centro de Referência em Doenças Infecciosas e Parasitárias. ${ }^{*}$ with radiographic confirmation.

Comorbidities were present in four patients (two with pulmonary tuberculosis, one with tuberculoid leprosy, and other with nonHodgkin lymphoma).

\section{Laboratory diagnosis, treatment, and control of cure}

Diagnostic confirmation was given through mycological exam in 14 patients, by mycological examination plus histopathology in 
6 patients, and isolated histopathology in 9 patients. Seventeen patients underwent chest radiography of which 11 showed lung lesions. As for hematological and biochemical tests, changes of the red series were predominant, featuring anemia. The aminotransferases were increased more than 20 times the normal value in one patient.

The treatment of 28 patients was performed on an outpatient basis, 15 with sulfametoxazole and trimethoprim, 11 with ketoconazole, and 2 with itraconazole. A 49-year-old, alcoholic and critically ill patient was hospitalized for treatment with amphotericin B. On the second day, he presented encephalopathy and pulmonary embolism and then ended in death.

In patients treated with sulfamethoxazole and trimethoprim, nine were followed up until the cure, and five did not respond satisfactorily to treatment. One patient, due to drug intolerance, was given a ketoconazole treatment as a replacement and obtained a good response.

In patients treated with ketoconazole, nine were followed up until discharge; one failed to respond to treatment, and amphotericin B treatment was administered; and another presented asthenia and darker skin at 3 months of treatment. Then, the drug was replaced by itraconazole. Patients treated with itraconazole had satisfactory outcome.

\section{DISCUSSION}

Paracoccidioidomycosis was found in 80 (36.8\%) municipalities of Maranhão, with $74 \%$ of cases located in the center and the west regions, which commonly have rainy and humid weather. The farming practice in these regions uses the expedient of burning, and the products are cassava flour, rice, bean, corn, watermelon, and sugar cane. The western region keeps the practice of vegetal extraction and the removal of firewood and logs for charcoal production. Moreover, the cultivation of eucalyptus reaches large areas ${ }^{16}$.

Studies have shown that the expanding population in the west of Maranhão began in the 1950s with the construction of highways linking Pará and Maranhão to Brasilia and the formation of settlements for workers and farmers from other states in the north and northeast. Historically, this fact can be considered as the beginning of the colonization and development of agricultural and livestock activities in a more extensive way, affecting the native forest and leaving the soil unprotected. One and another activity deserves attention for the contamination of soil and spread of Paracoccidioides brasiliensis, which marks the presence of the disease in the environment ${ }^{16,17}$. Since the 1980s, the establishment of steel mills in the western region has contributed to new environmental changes. The large amount of heat being produced by the furnaces of the industry raises the temperature in a region where silviculture is still incipient, worsened by the devastation of the forests for the production of charcoal that is supplied to industrial parks. Charcoal production produces smoke and soot.

The municipality of Açailândia has seven steel mills, apart from Vale and Petrobras. This is in conjunction with the municipalities of Imperatriz and Buriticupu that registered $46.7 \%$ of the reported cases of paracoccidioidomycosis in the west region. Its strategic position in the region and its development attract workers of the States Tocantins and Pará who also receive workers from Maranhão. Large numbers of cases from those states that have ecological and environmental conditions similar to those of Maranhão concerning the risk of exposure to Paracoccidioides brasiliensis were reported ${ }^{4}$. The same author found six sources in nature of Paracoccidioides brasiliensis in municipalities located in the west region of Maranhão and did not find autochthonous cases in the north, east, and south regions, concluding that sceneries are ecologically different from those that had autochthonous cases, probably due to broad climatic variation. Almeida and Albarelli were the first to suspect that the west of Maranhão had possible sources in nature of Paracoccidioides brasiliensis ${ }^{13}$.

The involvement of children under 4 years old reached $9.7 \%$ in this study's case series. It should be noted that in IDTNP-PI, the number of patients aged 0-19 years is higher than those found in CREDIP-MA, although this is a reference service that serves adults and children. Some hypotheses were raised when children from the States of Maranhão, Pará, and Tocantins were found with paracoccidioidomycosis, such as they were living in a rural area very close to the forest, present protein-energy malnutrition, and taking turns working in the farm and at charcoal house, which can intensify direct contact with the fungus ${ }^{4}$. The rapid increase of the population gave rise to settlement areas deforested for agriculture and livestock, and this could have caused the increase of juvenile cases. The low pathogenicity of Paracoccidioides brasiliensis and its long latency period can also be speculated on. Even with the infection occurring in childhood, the disease can manifest only during adulthood because of the reactivation of an endogenous focus ${ }^{1}$.

The higher prevalence of the disease in men requires more detailed observation. Studies using skin tests with paracoccidioidin showed comparable reactivity in both genders, which implies equal exposure to the fungus ${ }^{18}$.

In the clinical study of 29 patients diagnosed in the Centro de Referência em Doenças Infecciosas e Parasitárias at Universidade Federal do Maranhão (UFMA), the factors that aggravate the disease, such as alcohol use, smoking, poor diet, and association with other diseases, were observed. Considering the time of illness, the clinical presentation, and the age of patients, $89.6 \%$ of the cases could be classified as chronic multifocal forms ${ }^{1}$.

Association with other diseases was noticed in 4 patients, and this is in accordance with other authors who recorded comorbidities such as pulmonary tuberculosis, lymph node tuberculosis, leprosy, Hodgkin's disease, lung carcinoma, sporotrichosis, chromoblastomycosis, cutaneous leishmaniasis, histoplasmosis, cryptococcosis, and others ${ }^{1,19}$.

The treatment of paracoccidioidomycosis is difficult, and the patient usually seeks medical care only when multiple stigmas show up, which make the disease more difficult to cure ${ }^{3}$. This is the case in some of the patients in this study who when came to the service had gone through several services and doctors, without having been diagnosed accurately. The drug that had more effective results was ketoconazole, similar to the observation of other authors ${ }^{20}$. Treatment with sulfamethoxazole-trimethoprim was unsuccessful in $40 \%$ of the patients, showing that Paracoccidioides brasiliensis changed patient's sensitivity to that association over time, proving the points cited by the founders of the Brazilian Consensus of Paracoccidioidomycosis ${ }^{1}$. Amphotericin B was the drug of choice for treatment of severe cases, recurrences and intolerance, or hypersensitivity to other drugs. Twenty-seven patients were treated as outpatients and followed up monthly during the first six months and then every three months until the end of the treatment. 
In paracoccidioidomycosis, it is important to remember that the treatment goes beyond the choice of drug because considering the nature of the disease and the profile of the individuals affected is imperative to ensure the success of the treatment through followups and medication.

\section{CONFLICT OF INTEREST}

The authors declare that there is no conflict of interest.

\section{FINANCIAL SUPPORT}

This study was supported by Conselho Nacional de Desenvolvimento Científico e Tecnológico (CNPq) and Fundação de Amparo à Pesquisa e ao Desenvolvimento Tecnológico do Maranhão (FAPEMA).

\section{REFERENCES}

1. Shikanai-Yasuda MA, Telles Filho FQ, Mendes RP, Colombo AL, Moretti ML. Consenso em Paracoccidioidomicose. Rev Soc Bras Med Trop 2006; 39:297-310.

2. Fava Netto FC. Ocurrencia familiar de Blastomicose Sul-Americana. A propósito de 14 casos. Rev Inst Med Trop São Paulo 1965; 3:332-336.

3. Valle ACF, Wanke B, Wanke N, Peixoto TC, Perez M. Tratamento da paracoccidioidomicose: estudo retrospectivo de 500 casos. I- Análise clínica, laboratorial e epidemiológica. Ann Bras Dermatol 1992; 67:251-254.

4. Veras KN. Paracoccidioidomicose: estudo epidemiológico e clínico de pacientes internados no Hospital de Doenças Infecto-Contagiosas (HDIC) em Teresina, Piauí. Identificação de Reserváreas nos Estados do Pará e Maranhão, 1995. [Masthers Dissertation]. [Rio de Janeiro]: Instituto Oswaldo Cruz, Fundação Oswaldo Cruz; 1995. 196 p.

5. Oliveira PT, Yurgel LS, Lorandi CS, Moraes ACS. Estudo de 54 casos de paracoccidioidomicose diagnosticados no Serviço de Estomatologia do Hospital São Lucas da PUCRS. R Med PUCRS 1997; 7:161-166.

6. Palheta-Neto FX, Moreira JS, Martins ACC, Cruz FJ, Gomes ER, Pezzin-Palheta AC. Estudo de 26 casos de Paracoccidioidomicose avaliados no Serviço de Otorrinolaringologia da Fundação Oswaldo Cruz (FIOCRUZ). Rev Bras Otorrinolaringol 2003; 69:622-627.
7. Paniago AMM, Aguiar JIA, Aguiar ES, Cunha RV, Pereira GROL, Londero AT, et al. Paracoccidioidomicose: estudo clínico e epidemiológico de 422 casos observados no Estado de Mato Grosso do Sul. Rev Soc Bras Med Trop 2003; 36:455-459.

8. Verli FD, Marinho SA, Souza SC, Figueiredo MAZ, Yurgel LS. Perfil clínicoepidemiológico dos pacientes portadores de paracoccidioidomicose no Serviço de Estomatologia do Hospital São Lucas da Pontifícia Universidade Católica do Rio Grande do Sul. Rev Soc Bras Med Trop 2005; 38:234-237.

9. Coutinho ZF, Silva D, Lazéra M, Petri V, Oliveira RM, Sabroza PC, et al. Paracoccidioidomycosis mortality in Brazil (1980-1995). Cad Saude Publica 2002; 18:1441-1454.

10. Wanke B, Valle ACF, Zancopé-Oliveira RM, Costa RLB. Paracoccidioidomicose In: Coura JR, editor. Dinâmica das Doenças Infecciosas e Parasitárias. Vol. 2. Rio de Janeiro: Guanabara Koogan; 2005. p. 1193-1206.

11. Instituto Brasileiro de Geografia e Estatística (IBGE).Zoneamento Geoambiental do Estado do Maranhão. Brasília: IBGE; 1997.

12. Universidade Estadual do Maranhão(UEMA).Laboratório de Geoprocessamento - Núcleo Geoambiental: Page [Internet]. São Luis: UEMA; 2008. [Cited 2009 June 01] Available from: www.labgeo.uema.br/.

13. Almeida IF, Albarelli AL. Paracoccidioidomicose: ocorrência no Maranhão. Rev Hosp Serv Estado do Maranhão 1988; 2:19-25.

14. Oliveira MCLM. Paracoccidioidomicose- aspectos epidemiológicos com ênfase no perfil residencial dos pacientes. Rev Soc Bras Med Trop 1992; 25:138.

15. Instituto Brasileiro de Geografia e Estatística (IBGE). Séries Estatísticas [Internet]. Brasília: IBGE; 2010. [2011 April 23] Available from: http://www. ibge.gov.br/series_estatisticas/.

16. Feitosa AC, Trovão JR. Atlas Escolar do Maranhão: espaço geo-histórico e cultural. João Pessoa: Grafset; 2006.

17. Coelho Neto E. Geo-História do Maranhão. São Luís: Serviço de Imprensa e Obras Gráficas do Estado (SIOGE); 2001.

18. Cavallo M, Díaz A, Jiménez M, Jiménez R, Katiraee B, Rojas O. Estudio epidemiológico de la paracoccidioidomicosis en la comunidad de Guapa, municipio Andrés Eloy Blanco, Estado Lara, Venezuela, octubre 2001-febrero 2002. Rev Soc Ven Microbiol 2002; 22:158-163.

19. Quagliato Jr R, Grangeia TAG, Massucio RAC, Capitani EM, Rezende SM, Balthazar AB. Associação entre paracoccidioidomicose e tuberculose: realidade e erro diagnóstico. J Bras Pneumol 2007; 33:295-300.

20. Restrepo A, Stevens DA, Leiderman E, Fuentes J, Arana A, Angel R, et al Ketoconazole in paracoccidioidomycosis: lung therapy study with prolonged oral therapy. Mycopathol 1980; 72:35-45. 